\title{
Residential property ownership valuation and cost management based on energy efficiency measures
}

\author{
Sergey Baronin ${ }^{1, *}$ and Kirill Kulakov ${ }^{2}$ \\ ${ }^{1}$ Penza State University of Architecture and Civil Engineering, 27, Titova street, Penza, 440027, \\ Russia \\ ${ }^{2}$ Moscow State University of Civil Engineering, 26 Yaroslavskoye Shosse, Moscow, 109377, Russia
}

\begin{abstract}
The aim of the research is to work out theoretical provisions to model processes of estimating and managing costs of owning residential realty on the basis of measures aimed at increasing energy efficiency. The existing Russian and foreign experience in the field of investigated topic is provided. The proprietary methodology for calculating the cost of owning residential realty and managing it in accordance with actual expenditures for the purposes of their minimizing is described. The methodology was tested on a single apartment, a section of residential building and a whole apartment house in the city of Penza, pertaining to certain homeowners. The structure of expenditures of an owner was analyzed on the basis of Pareto chart and ABC-analysis; indicators of ownership within yearly, monthly and daily cycles for the period from 2014 to 2019 were calculated. The effect of owning residential real estate in the context of its secondary sale was demonstrated. The measure consists in using the innovative heating boiler ATP-TermaRON within the limits of, first, a single apartment, second, a cluster-system of homeowners living in one section of a building, and, third, a whole apartment house. Some basic conclusions on the problematics under consideration were made and certain recommendations were given.
\end{abstract}

\section{Introduction}

The author's research shows [1] that the field of problems associated with studying the ontological understanding of the development of valuation activities in Russia on the basis of the value concept of ownership in relation to residential real estate is formed in the context of the global trend of applying the concept of Total Cost of Ownership (TCO) [2], as well as under conditions of developing domestic practice of assessing life cycle [3] when purchasing products for state and municipal needs in accordance with Federal Law 44-FZ on ensuring the priority of innovative and high-tech products [4].

The analysis showed that the first methodology (and the only one in Russia so far) for assessing life cycles of buildings in terms of total costs, which is applicable for state lifecycle contacts, is the methodology of self-regulatory organization for design workers [5]. It gives the opportunity to calculate total costs at the stage of detailed design on the basis of

* Corresponding author: baron60@inbox.ru 
anticipated data on operation taking into account the requirements of environmental friendliness, energy efficiency and discounting. This methodology should be attributed to tender documents for public procurement. It may be considered the first step towards calculating TCO.

Investigation into methodological aspects of modeling the concept of appraising life cycles as part of valuation activities in Russia [5] showed that domestic valuation activities tend to use not only traditional values (market, investment, etc.), but also valuation focused on various types of the cost of life cycles.

Modern efficient economy requires to valuate various types of products (works) as costs of life cycle contracts (LCC) [7], the maximum initial cost of LCC and the cost of ownership [8], including for capital construction projects. Despite their complexity, the problem of cost modeling of life cycles of construction of a building in terms of total costs, as well as valuation of cost of life cycle contracts for real estate, are actively explored by researchers [9].

Herewith the processes of valuation activities' development in terms of value management can be defined as the genesis of value management and modern transition to cost management for life cycle contracts and real estate ownership [10].

The problematics of managing total cost of life cycles of real estate with different energy efficiency also receives certain attention $[11,12]$.

TCO in its general form can be defined as a concept that explains the cost of ownership in relation to a life cycle (LC) of any type of product, system or work as the sum of combined costs of ownership for a certain period.

Specifics of residential real estate operation predetermines its special requirements for TCO models. It has also predetermined the subject of our study: the residential real estate market, which is considered as a special type of cluster system of homeowners, in the context of implementing energy efficient measures aimed at reduction of costs of ownership.

The operational hypothesis of the study suggests that filling the need to develop the Russian national idea of an economically responsible homeowner requires the use of institutional tools in order to minimize expenses for all types of homeowners on the basis of large-scale programs and measures aimed at improvement of energy efficiency and cost effectiveness.

In this regard, there was set the goal to develop theoretical provisions and methodological approaches to modeling the processes of valuating and managing the cost of owning residential real estate on the basis of energy-efficient measures. It is assumed a type of valuation of life cycles of capital construction projects during their operation with respect to homeowners and accounting periods of ownership.

The scientific novelty of this research consists in a complex of scientific principles, conceptual approaches, methodologies, methodological approaches and techniques for the cost modeling of processes of valuating and managing costs of owning capital construction projects, which are shown in terms of owning residential real estate.

\section{Methods}

The studies performed allowed suggesting the author's version of the methodology for calculating the cost of owning residential real estate at the stages of its operation with the use of actual ownership costs for the purpose of modeling its management on the basis of energy efficient measures.

Yet in terms of methodology, the cost of ownership should be perceived as a special case of valuation of life cycles of real estate objects. It should also be noted that calculation of costs of ownership based on actual costs and the subsequent formation of standards for costs of owning real estate is assumed a promising criterion of efficiency of the investment and 
housing policy in Russia. This enables considering the minimization of costs of owning capital construction objects for end users (owners) as the main criterion for managing the reproduction of residential real estate, as well as avoiding the reduction of capital investments considering it the main indicator of construction efficiency.

In general form, the cost of owning $\left(\mathrm{C}_{\text {own }}\right)$ residential real estate is proposed to calculate as the sum of one-time expenditures spent by the homeowner for purchasing (or constructing) a property to the date of taking ownership $\left(E_{\mathrm{P}}\right)$ and the total annual expenditures of ownership $\left(\mathrm{E}_{\text {taeown }}\right)$ spent by the owner for the period from the moment of taking ownership $\left(\mathrm{T}_{0}\right)$ until the moment of its termination $\left(\mathrm{T}_{\mathrm{T}}\right)$.

This conceptual approach is proposed to formalize methodically by the following formula (1):

$$
C_{\text {own }}=E_{P}\left(T_{0}\right)+\sum_{T_{0}}^{T_{T}} E_{\text {taeown }}
$$

In this case, the period of owning real estate $\mathrm{T}_{\text {own }}$ for the owner is determined as follows:

$$
T_{\text {own }}=T_{T}-T_{0}
$$

Total annual expenses associated with ownership $\mathrm{E}_{\text {taeown }}$ are advised to calculate within annual cycles. Therewith, monthly expenses of owners taken in accordance with actual data of a homeowners' association or Home Unit Company are offered to use as the minimum cost cycle of ownership. Then the calculation formula for $\mathrm{E}_{\text {taeown }}$ takes the following form:

$$
\sum_{T_{0}}^{T_{T}} E_{\text {taeown }}=\sum_{T_{0}}^{T_{T}} \sum_{i=1}^{12} E_{\text {taeown }_{i}}=\sum_{T_{0}}^{T_{T}} \sum_{i=1}^{12}\left(E_{\text {Oi }}+E_{\text {OWNi }}\right)
$$

where $\mathrm{E}_{\mathrm{Oi}}$ is for total monthly operating expenditures;

EOwni is for annual title ownership expenditures.

In turn, the structure of costs of owning $E_{\text {taeown }}$ is composed of:

Firstly, monthly operating expenditures, which are calculated as a multi-component member through the types of local costs:

$$
E_{O i}=E_{G i}+E_{P S U i}+E_{E L i}+E_{M S W i}+E_{W S D i}+E_{H i}+E_{C R i}
$$

where $\mathrm{E}_{\mathrm{Gi}}$ is for monthly expenses for gas supply;

$\mathrm{E}_{\mathrm{PSUi}}$ is for monthly expenses for public-service utilities (homeowners' association);

$\mathrm{E}_{\mathrm{ELi}}$ is for monthly expenses for electricity;

$\mathrm{E}_{\mathrm{MSWi}}$ is for monthly expenses for municipal solid waste collection and disposal;

$\mathrm{E}_{\mathrm{WSDi}}-$ is for monthly expenses for water supply and disposal;

$\mathrm{E}_{\mathrm{Hi}}$ is for monthly expenses for heat supply;

$\mathrm{E}_{\mathrm{CRi}}$ is for monthly expenses for capital repairs.

Secondly, annual title expenditures of a homeowner, namely a property tax for individuals, real estate insurance costs, expenses associated with paying for real estate services when buying or selling real estate, and others:

$$
E_{\text {OWNi }}=E_{P T I i}+E_{I N S i}+E_{\text {OTH }}
$$

where $\mathrm{E}_{\mathrm{PTIi}}$ is for expenses associated with the property tax for individuals;

$\mathrm{E}_{\text {INSi }}$ is for annual expenses for insurance;

$\mathrm{E}_{\mathrm{OTH}}$ is for other expenses.

The methodology for the cost of owning real estate provides for the calculation of indicators of $\mathrm{C}_{\text {own }}$ both in absolute terms for a certain period and in relative terms per $1 \mathrm{~m}^{2}$ of total area or living space. This is represented through the following formula: 


$$
C_{\text {own }}^{m^{2}}=\frac{\mathrm{C}_{o w n}}{S}
$$

where $\mathrm{C}_{\text {own }}$ is for the cost of owning residential real estate,

$\mathrm{S}$ is for living space or total area of real estate.

In addition, it is proposed to calculate the cost of ownership in terms of various types of owners, namely: a single homeowner or several homeowners. In this case, the formula for the cost of ownership takes the following form:

$$
\mathrm{C}_{\text {own }}^{N}=\frac{C_{o w n}}{N}
$$

where $\mathrm{C}_{\text {own }}$ is the cost of owning residential real estate;

$\mathrm{N}$ is the number of homeowners.

Cost of owning residential real estate is proposed to calculate both for a retrospective period according to actual data on total cost of ownership, and as a predicted value for a certain period, on the basis of assumed models of change in costs in accordance with the accepted trends.

The final stage of modeling ownership valuation implies determination of the effect of ownership of real estate for the owner in the context of reselling property for the estimated periods of ownership in case of ownership termination. In this case, the effect of ownership $\left(\mathrm{Ef}_{\text {own }}\right)$ is determined according to the following formula:

$$
E f_{\text {own }}=\mathrm{C}_{\text {res }}-\mathrm{C}_{\text {own }}
$$

where $\mathrm{C}_{\text {res }}$ is the resale value of residential real estate,

$\mathrm{C}_{\text {own }}$ is the cost of owning residential real estate.

It should be noted that this formula to calculate $\mathrm{Ef}_{\text {own }}$ is valid as long as a real estate object is resold within a period that does not exceed the life cycle of this object.

A three-level model of managing costs of owning residential realty is proposed to use by means of controlling actions $\mathrm{R}$. These actions imply energy efficient measures involving certain capital costs aimed at reducing $\mathrm{C}_{\text {own }}$.

Real estate owners, particularly a special cluster system of homeowners "apartment $\left(\mathrm{ME}_{1}\right)$-section $\left(\mathrm{ME}_{2}\right)$-house $\left(\mathrm{ME}_{3}\right)$-street block $\left(\mathrm{ME}_{4}\right)$-neighborhood unit $\left(\mathrm{ME}_{\mathrm{j}}\right)$ ", are proposed to be considered as management entities ME. The context is the implementation of energy efficient measures $\mathrm{R}$ of both local $\left(\mathrm{R}_{1}\right)$ and public $\left(\mathrm{R}_{2-\mathrm{j}}\right)$ types aimed at reducing the basic level of the cost of ownership $\mathrm{C}_{\mathrm{own}} \mathrm{OO}^{\mathrm{O}}$ to the expected level by taking energy efficient measure $\mathrm{W}_{1-\mathrm{j}}$, when the effect of reducing the cost of ownership is observed for different types of homeowners $\left(\Delta \mathrm{C}_{1-\mathrm{j}}\right)$.

This study implies that subject of management SM are a local residential apartment $\left(\mathrm{SM}_{1}\right)$, a group of apartments in a building section $\left(\mathrm{SM}_{2}\right)$ and a group of apartments in a whole apartment building $\left(\mathrm{SM}_{3}\right)$.

Thus, various entities of residential real estate management considered as a special type of cluster system of owners united by a single real estate and having common goals to reduce the cost of ownership with varying extent of effects (effectiveness).

\section{Results}

The elaborated methodological apparatus for calculating the total cost and the effect of real estate owning is to be tested on the example of a two-room apartment with a total area of 43 $\mathrm{m}^{2}$, located in the city of Penza, 31 Belyaeva St. 
To calculate the total cost of owning the subject property, the previously indicated formula (1) is to use. At the same time, the estimated ownership period was taken from 2003 (the year of acquiring the property for 380 thousand rubles) to the end of 2020 (resale of the property at a market value of 1.5 million rubles):

$$
C_{\text {own }}^{\text {OO }}=E_{P}^{2003}+\sum_{2004}^{2020} E_{\text {taeown }}
$$

To calculate $\mathrm{E}_{\text {taeown }}$, all costs incurred during ownership have been analyzed. In our case, $\mathrm{E}_{\text {taeown }}$ is the sum of utility costs, contributions for major repairs and property tax of individuals:

$$
\begin{aligned}
& \sum_{2004}^{2020} E_{\text {taeown }}=\sum_{2004}^{2020} \sum_{i=1}^{12} E_{\text {taeowni }}=E_{O i}+E_{\text {OWNi }}= \\
& =E_{G i}+E_{P S U i}+E_{E L i}+E_{M S W i}+E_{W S D i}+E_{H i}+E_{C R i}+E_{P T i}+E_{O T H i}
\end{aligned}
$$

where $E_{\mathrm{Gi}}$ is monthly expenses for gas supply; $\mathrm{E}_{\mathrm{PSUi}}$ is monthly expenses for public-service utilities; $E_{E L i}$ is monthly expenses for electricity; $\mathrm{E}_{\mathrm{MSWi}}$ is monthly expenses for municipal solid waste collection and disposal; $E_{W S D i}$ is monthly expenses for water supply and disposal; $\mathrm{E}_{\mathrm{Hi}}$ is monthly expenses for heat supply; $\mathrm{E}_{\mathrm{CRi}}$ is monthly expenses for capital repairs; $\mathrm{E}_{\mathrm{PTi}}$ is property tax for individuals; $\mathrm{E}_{\text {Отн }}$ is other expenses.

Within the analysis, the authors obtained and analyzed values and the structure of expenditures $\mathrm{E}_{\text {taeown }}$ associated with ownership on the basis of actual payment documents. The structure and share of expenditures for monthly payments of the owner are shown in Fig. 1 .



Fig. 1. Structure of the average share of monthly expenditures for owning residential real estate according to local indicators of $E_{\text {taeown }}$ for the ownership period from 2015 to 2019.

The graph shows that expenses for heat supply reach their peak during the heating period from October to April. Their share significantly exceeds the share of other expenditures; in February it reaches its maximum $-49.2 \%$ of all expenditures associated with ownership. 
The use of the elaborated methodological apparatus allowed determining the total value of $E_{\text {taeown }}$ from 2004 to 2020 in the amount of 559809 rubles, as well as the total cost of ownership $\mathrm{C}_{\mathrm{own}}^{\mathrm{OO}}$ in the amount of 939809 rubles.

The process of modeling the graph of change in the total cost of ownership for the entire period of owning the apartment is shown in Figure 2.

The graph illustrates that at the time of taking ownership in 2003, the total cost of owning the residential real estate $\mathrm{C}_{\mathrm{own}}^{\mathrm{OO}}$ was 380,000 rubles, which equaled the initial acquisition expenses. Therewith, $\mathrm{C}_{\text {own }}^{\mathrm{OO}}$ was increasing annually by the value of $\mathrm{E}_{\text {taeown }}$, so that by the time of terminating the ownership it reached 939,809 rubles. The annual growth of $\mathrm{C}_{\mathrm{own}}^{\mathrm{OO}}$ is averagely quite stable and amounts to about $6 \%$. The growth in the total cost of ownership of the subject property $\mathrm{C}_{\text {own }}^{\mathrm{OO}}$ for 2020 by the time of terminating the ownership rights was $247.32 \%$.

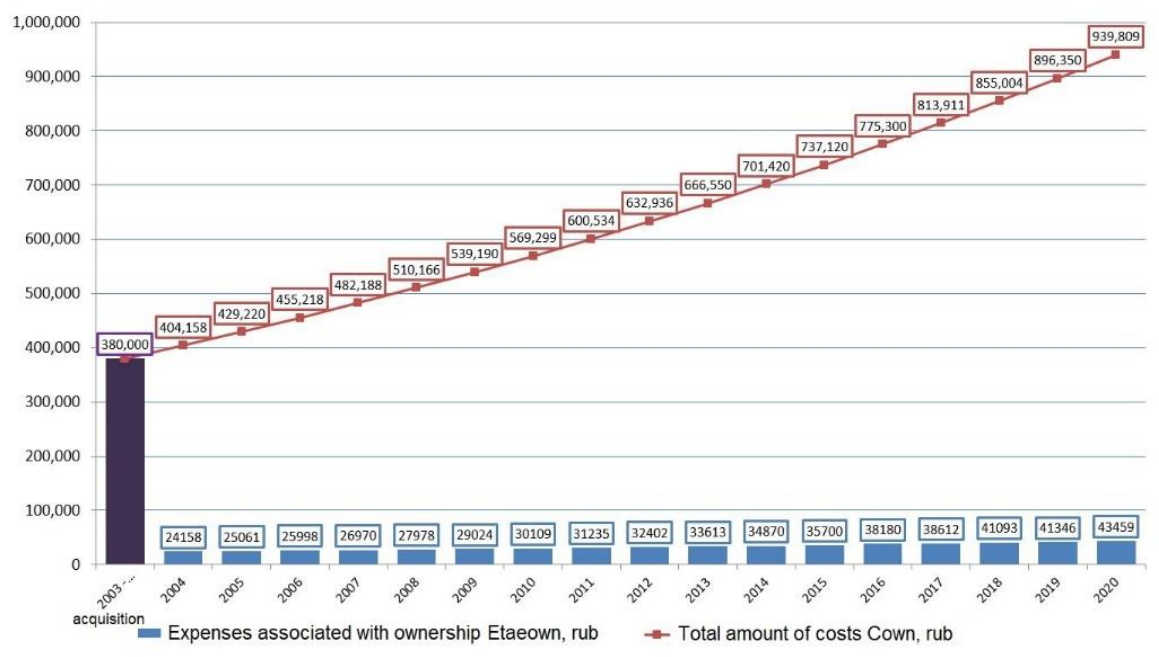

Fig. 2. Modeling the changes in annual values of the total cost of owning real estate: both differential expenditures of owning $E_{\text {taeown }}$ and the integral accumulated amount of costs $C_{\text {own }}$ for the entire period of ownership in 2003-2020 taking into account the cost of purchasing the apartment.

The analysis showed that the average cost of ownership for this apartment for one month amounted to 31,667 rubles per month in 2003 and has changed to 78,317 rubles per month in 2020. Accordingly, the cost of one day of ownership has changed from 1,041 rubles per day to 2,575 rubles per day. The average annual growth in the cost of ownership of the apartment is $6 \%$.

The calculation of specific indicators of the total cost of ownership $\mathrm{C}_{\mathrm{own}}^{\mathrm{OO}}$ per $1 \mathrm{~m}^{2}$ during the entire period of ownership showed the following values: a) the monthly cost of owning 1 square meter is 736 rubles per month (2003) and 1821 rubles per month (2020); b) daily cost of owning $1 \mathrm{~m}^{2}$ is 24 rubles per day (2003) and 60 rubles per day (2020).

The effect of owning this residential property $\mathrm{Ef}_{\text {own }}$ was calculated by the formula (8), subject to its resale at the end of 2020. The effect of ownership amounted to 584,874 rubles. A graphical model of this value paradigm is shown in Figure 3. 




Fig. 3. Graphic modeling of the extent of the effect of owning a residential real estate $\mathrm{Ef}_{\mathrm{own}}$ for the period of ownership since 2003 subject to its resale in 2020.

The final stage of the study included the modeling of management processes for reducing the cost of ownership through innovative activities. The performed analysis of the structure of expenditures associated with ownership $\mathrm{E}_{\text {taeown }}$ showed that it is possible to achieve the maximum reduction in the total cost of ownership by, firstly, reducing operating expenses for heating, the share of which reaches 50\% during the heating season. For these purposes, it was decided to forgo central heating and hot water supply in favor of the highly efficient molecular boiler ATP-TermaRON (developed by V.A. Tolstolugov). Due to waveresonance, cavitation, molecular-cluster and ionization processes, it converts $1 \mathrm{~kW}$ of electrical power into $3.6 \mathrm{~kW}$ of thermal energy, which lowers the heat and hot water bills by more than $300 \%$.

The performed studies have shown that despite the reduction in total expenditures for ownership $\mathrm{E}_{\text {taeown }}$, installing ATP-TermaRON in a separate residential apartment is economically unreasonable because of the long payback period of 51 years. At the same time, the maximum reduction in expenses associated with ownership $\mathrm{E}_{\text {taeown }}$ and the cost of ownership $\mathrm{C}_{\text {own }}{ }^{\mathrm{OO}}$ with the shortest payback period of 1.76 years can be obtained by intriducing two ATP-TermaRON/MidiTERM boilers in a residential building where the apartment under consideration is located. In this case, the maximum reduction in the cost of ownership is ensured; the payback period of the project will amount to 1.76 years.

\section{Discussion}

The concept of Total Cost of Ownership, which is quite seldom used in Russian construction and operation practice, may be referred to the set of problematic issues of applying the valuation of cost of owning residential real estate and managing its reduction based on measures aimed at improving energy-efficiency.

The analysis showed that this approach is mostly applicable to information systems and technologies, on the car market (when indicators of the cost of owning a car are actively used in advertising campaigns), in the procurement of signaling systems in railway transport. 
There are examples of modeling the cost of ownership when selling water purification filters. A manufacturer appraises the ownership of a filter as of a life cycle by determining not only the initial purchase cost, but also the subsequent operating expenses for replacing elements of a filter compared to their competitors.

The analysis shows that the housing market requires the calculation of the cost of ownership, but only in case of purchasing foreign real estate. There is a commonly used real estate practice when the level of tax payments, which can be significant in certain countries, is additionally specified for the buyer.

The active practice of calculating of the cost of owning real estate in construction is only at the initial stage of introduction and requires additional motivation for all market participants.

The value model for ownership is one of the interpretations of understanding the cost of a product or work as the cost of their life cycle. In this regard, the development of using value models for ownership is associated with the development of national economic thinking in the field of expanding the application of the theory and practice of managing economic systems as life cycles with valuation of these systems in order to minimize cost of owning in relation to certain owners.

The analysis showed that TCO models are actively used in developed economies. For example, the American National Standards Institute developed the APPA 1000-1 standard in 2017, [13] which was supplemented with new clarifications in 2019 [14].

In Russia, the Ministry of Construction of the Russian Federation adopted the concept of life cycle management of capital construction objects via information modeling. Moreover, federal standards are being developed, yet only traditional indicators of the effectiveness of investment and construction projects are used, such as NPV, payback period, profitability index, etc. Development and application of national standards in the investment and construction sector based on TCO are not executed, although there are some local studies in this area [5-12].

We believe that this topic requires additional discussion by the expert community of the investment and construction sphere; this scientific and practical topic certainly should be debatable and creative.

We consider it important to primarily use this methodological approach when implementing all national projects of Russia. Russia needs the transition to management of capital construction projects based on TCO models. According to the author's expert data, in national projects, the use of the concept of managing long-term life cycles of development of industries, enterprises and investment projects based on the cost of ownership allows generating processes of a significant acceleration of the efficiency of project implementation in comparison with conventional models.

The analysis showed that individual local studies to determine indicators of the cost of owning residential real estate in terms of the total costs of life cycles of buildings were carried out in Russia [15]. The data obtained indicate that the average rates of cost of ownership for operation periods of 50 years form the following structure: $20 \%$ is a one-time acquisition expenditure; $80 \%$ is the owner's total operating expenditures.

Similar author's studies related to this area allowed calculating average expert indicators of the structure of owning motor roads in Russia for an estimated period of 50 years. The result is the following ratio: $99 \%$ is the total operating costs; $1 \%$ is a one-time capital expenditure on road construction [16]. These proportions of the cost of owning roads are quite consistent with the existing fairly costly technique of their construction, which contain significant annual amounts of their current and major repairs prevailing due to low quality of roads. Shifting the focus to TCO during road construction can provide a new understanding of its efficiency in terms of the cost of road ownership. There are no official TCO methodologies and standards for the cost of ownership for end users and owners now. It 
would be challenging and promising for the Russian economy to develop these indicators and use them when implementing innovative state strategies for control over this industry.

We consider it reasonable both when implementing National Projects and exercising the public procurement function under Federal Law 44-FZ in relation to the processes of management of capital construction facilities to introduce mandatory TCO regulations along with the use of life cycle contracts.

It is proposed to start developing a Russian national standard for this area, similar to the American standard APPA 1000-1 - Total Cost of Ownership for Facilities Asset Management (TCO). It is timely and viable to include its elaboration into the current plan of Federal Agency on Technical Regulating and Metrology Rosstandart as part of the work of the technological committee TK465 "Construction".

\section{Conclusions}

The research performed has confirmed the relevance of studying the subject under consideration, which is related to the development of valuation activities in Russia based on the methodology for appraising and managing the cost of owning residential real estate, as well as other capital construction projects.

We consider it reasonable to develop the institution of a responsible owner in Russia on the basis on minimizing the burden of owning various types of residential realty, as well as other types of real estate.

It is proposed to consider this approach as a special type of developing innovative strategy for managing the construction of real estate objects based on life cycles of construction, operation and ownership in order to minimize the cost of ownership.

We believe that it is important to update the current domestic trend in the development of valuation activities in Russia based on the innovative cost type in the form of the cost of ownership, which results from the genesis of appraisal and management of cost of life cycles of products, works and capital construction projects.

The author's methodology for appraisal of owning residential real estate at the stages of its operation proceeding from actual costs was tested for a two-room apartment in Penza with a total area of $43 \mathrm{~m}^{2}$. The test proved the effectiveness of the methodology developed. For the period of ownership from 2003 to 2020, the structure of average monthly shares of the expenses for owning residential real estate and its dynamics were defined; the effect of ownership after the resale was calculated.

Management processes were modeled for reducing the cost of ownership through innovative measures that lessen operating expenses for heating, the share of which may reach up to $50 \%$ during the heating period. The use of a highly efficient molecular boiler with cavitation, molecular-cluster and ionization processes enabled lowering heat and hot water bills by more than $300 \%$, which significantly reduced the cost of ownership and ensured a 1.7-year payback period.

It seems important to keep doing the theoretical and scientific-and-practical modeling of applying the concept of the cost of ownership as a complex of organizational and economic relations and interactions between the owners and the subjects of ownership for the estimated periods within the process of appraising and modeling the management of reducing the cost of ownership on the grounds of measures that increase energy efficiency.

The multi-format phenomenon of the concept of the cost of ownership and the need for its reduction requires its creative application at all stages of the life cycle of real estate construction management. Additionally, the successful foreign experience in this area should be used when analyzing the possibilities to use them in the development of national standards on the basis of TCO within the process of construction and operation. 


\section{Acknowledgment}

The authors thank V.S. Kazeykin, the Academician of the International Academy of Mortgage and Real Estate, for creative cooperation in the research of foreign experience in valuation of the life cycle of capital construction projects according to TCO models, in analysis of Russian practices of energy efficiency management and in applying the methodology in Russian construction for appraising buildings in terms of combined costs.

We express our special gratitude to P.G. Grabovoi, Doctor of Economics, Prof., Honored Builder of Russia, Head of the Department of Construction Management and Property Administration of NRU Moscow State University of Civil Engineering, for scientific and practical advice in modeling life cycles of real estate, as well as in conceptual and methodological structuring of the problem of genesis of valuation activities on the basis of innovative ideas for cost management of life cycles, life cycle contracts and the cost of ownership of various types of real estate.

The authors are grateful to Vladislav Averyanov, a student of Penza State University of Architecture and Civil Engineering, for performing in his bachelor's thesis a complex of calculations for the cost of owning residential realty, which were used in the present paper.

\section{References}

1. K. Kulakov, S. Baronin, MATEC Web of Conferences. "International Science Conference SPbWOSCE-2016 "SMART City"'" 06022 (2017)

2. S.A. Baronin, A.G. Yankov, S.A. Bizhanov, Life Science Journal 11(8s), 249-253 (2014)

3. K.Y. Kulakov, S.A. Baronin, International Journal of Civil Engineering and Technology (IJCIET) 9(10), 1140-1148 (2018)

4. Federal Law of the Russian Federation "On the contract system in the field of procurement of goods, works, services to meet state and municipal needs" №-44FZ (2013)

5. Methodology for calculating the life cycle of a residential building, taking into account total costs (National Association of Designers, Moscow, 2014)

6. K.Y. Kulakov, Ekonomicheskiye strategii 4(170), 80-91 (2020)

7. S.A. Baronin, A.G. Yankov, Electronic research journal "Modern Problems of Science and Education" 6 (2013) http://www.science-education.ru/113-11588

8. T. Simankina, I. Kibireva, A. Mottaeva, M. Gusarova, Advances in Intelligent Systems and Computing 983, 138-145 (2019) https://doi.org/10.1007/978-3-030-19868-8_13

9. K.Y. Kulakov, S.A. Baronin, Nedvizhimost': ekonomika, upravleniye 1, 32-38 (2019)

10. S.A. Baronin, K.Y. Kulakov, Nedvizhimost': ekonomika, upravleniye 1, 10-14 (2020)

11. S.A. Baronin, Metodicheskiye aspekty formirovaniya $i$ upravleniya sovokupnoy stoimost'yu zhiznennykh tsiklov nedvizhimosti s raznym urovnem energoeffektivnosti. Monografiya (PGUAS, Penza, 2017)

12. K.Y. Kulakov, S.A. Baronin, Journal of Advanced Research in Law and Economics 6(2), 291-298 (2015)

13. APPA 1000-1 - Total Cost of Ownership for Facilities Asset Management (TCO). Part 1: Key Principles (2017)

14. APPA 1000-2 Total Cost of Ownership for Facilities Asset Management (TCO). Part 2: Implementation and Data Elements» (2019) 
15. Buka-Vaivade, K., Sliseris, J., Serdjuks, D., Pakrastins, L., Vatin, N.I. Magazine of Civil Engineering. 2018. 84(8). Pp. 3-14. DOI:10.18720/MCE.84.1.

16. Campian, C., Chira, N., Iuhos, V., Pop, M., Vatin, N. Procedia Engineering. 2016. 165. Pp. 876-882. DOI:10.1016/j.proeng.2016.11.787.

17. Chechevichkin, A.V., Vatin, N.I., Samonin, V.V., Grekov, M.A. Magazine of Civil Engineering. 2017. 76(8). Pp. 201-213. DOI:10.18720/MCE.76.18

18. S.A. Baronin, V.S. Grebenshchikov, A.G. Yankov, Nedvizhimost': ekonomika, upravleniye 3, 36-40 (2015)

19. S.A. Baronin, A.I. Yeremkin, I.K. Ponomareva, Nauchno-tekhnicheskiy zhurnal Regional'naya arkhitektura i stroitel'stvo 2, 10-14 (2020) 